\title{
Kohesivitas Dan Social Loafing Dalam Pembelajaran Kelompok Pada Siswa SMAN 1 Indralaya
}

\author{
Rita Rita \\ Program Studi Psikologi Universitas Sriwijaya \\ ritazainudin@gmail.com \\ Sayang Ajeng Mardhiyah \\ Program Studi Psikologi Universitas Sriwijaya \\ ajeng_mardhiyah.psi@fk.unsri.ac.id \\ Muhammad Zainal Fikri \\ Program Studi Psikologi Universitas Sriwijaya \\ mzainalfikri@gmail.com
}

\begin{abstract}
The research aims to determine the relationship between cohesiveness and social loafing on group learning at SMAN 1 Indralaya. The hypothesis of this research as a relationship between cohesiveness and social loafing on group learning at SMAN 1 Indralaya. The subject on this research was student of SMAN 1 Indralaya. The collecting technique using nonprobability sampling with a purposive sampling. The population on this research was 772 students and the sample was 250 students based on Isaac and Micheal theory. Cohesiveness and social loafing was measured by the scale of Cohesiveness and Social Loafing, with reference to the component of cohesiveness from Forsyth (2010) and dimensions of social loafing from Chidambaram and Tung (2005).The result of this research indicate cohesiveness has a relationship with social loafing on students of SMAN 1 Indralaya with a correlation coeffisien -0.745 and $p=0.000(p<0.05)$. Thus the hypothesis is accepted.
\end{abstract}

Key words: cohesiveness; social loafing; group learning

\begin{abstract}
Abstrak
Penelitian ini bertujuan untuk mengetahui hubungan antara kohesivitas dan social loafing dalam pembelajaran kelompok pada siswa di SMAN 1 Indralaya. Hipotesis dalam penelitian ini yaitu ada hubungan antara kohesivitas dan social loafing dalam pembelajaran kelompok pada siswa di SMAN 1 Indralaya. Subjek dalam penelitian ini yaitu siswa SMAN 1 Indralaya. Teknik sampling yang digunakan adalah nonprobability sampling dengan jenis sampling purposive. Populasi dalam penelitian ini sebanyak 772 orang, dan terpilih sebanyak 250 orang subjek melalui rumus Isaac dan Michael. Kohesivitas dan social loafing diukur dengan skala Kohesivitas dan Social Loafing, dengan mengacu pada komponen kohesivitas dari
\end{abstract}


Forsyth (2010) dan dimensi social loafing dari Chidambaram dan Tung (2005). Hasil uji hipotesis penelitian ini menunjukkan bahwa ada hubungan antara kohesivitas dan social loafing dalam pembelajaran kelompok pada siswa di SMAN 1 Indralaya dengan koefisien korelasi sebesar -0.745 dan $\mathrm{p}=0.000$ $(\mathrm{p}<0.05)$. Dengan demikian hipotesis yang diajukan diterima.

Kata Kunci : kohesivitas; social loafing; pembelajaran kelompok

\section{Pendahuluan}

Pendidikan penting bagi setiap orang. Melalui pendidikan seseorang dapat memperoleh pengetahuan dan keterampilan, sehingga meningkatkan kualitas pribadi seseorang. Salah satu faktor penting yang menentukan keberhasilan proses pembelajaran adalah guru (Darmadi, 2017). Guru memiliki peranan yang sangat strategis dalam memberdayakan siswanya. Kemampuan guru ini hendaknya didukung dengan metode pembelajaran yang baik, dimana dapat mempengaruhi keterlibatan siswa selama proses pembelajaran (Sujarwo, 2010).

Banyak pertimbangan yang harus dipahami oleh guru dalam menentukan metode pembelajaran yang tepat (Prastowo, 2015). Salah satu metode pembelajaran yang sering diterapkan di kelas yaitu metode kerja kelompok. Metode kerja kelompok merupakan proses pembelajaran dimana siswa-siswa dalam satu kelas dibagi ke dalam beberapa kelompok baik kelompok kecilmaupun kelompok besar untuk mencapai tujuan bersama (Usman, 2002).

Metode pembelajaran secara berkelompok memiliki dampak yang positif terhadap siswa. Menurut Darmadi (2017), kelebihan dari pembelajaran secara berkelompok yaitu kegiatan kelompok dapat meningkatkan kualitas kepribadian siswa, seperti adanya kerjasama, toleransi, berpikir kritis, disiplin, dan sebagainya (ditinjau dari segi pedagogis). Kemudian timbul persaingan yang positif antar kelompok karena mereka bekerja pada masing-masing kelompok (ditinjau dari segi psikologis). Serta anak yang pandai dalam kelompok dapat membantu anak yang kurang pandai dalam mengerjakan tugas (ditinjau dari segi sosial).

Namun metode kerja kelompok juga memiliki kelemahan. Usman (2002) menyatakan bahwa pembelajaran secara berkelompok memiliki beberapa kelemahan yaitu bagi siswa yang tidak memiliki disiplin diri atau malas terbuka kemungkinan untuk tetap pasif dan kemungkinan besar bisa mempengaruhi dan 
mengganggu kelompoknya sehingga kelompok tersebut mengalami kegagalan serta jika tugas yang diberikan kepada masing-masing kelompok tidak dibatasi dengan waktu tertentu, maka tugas tersebut cenderung terabaikan.

Kemudian Darmadi (2017) juga mengungkapkan salah satu kelemahan dari metode kerja kelompok menurut yaitu tugas-tugas yang diberikan kadang-kadang hanya dikerjakan oleh segelintir siswa yang cakap dan rajin, sedangkan siswa yang malas akan menyerahkan tugas-tugasnya kepada temannya dalam kelompok tersebut. Dommeyer (Tyagi, 2015), menyatakan bahwa perilaku dari anggota kelompok yang melalaikan kewajiban mereka dengan harapan memanfaatkan usaha orang lain disebut dengan social loafing.

Social loafing merupakan permasalahan yang serius di dalam kelompok dimana anggota kelompok cenderung melakukan pengurangan terhadap potensi mereka (Chidambaram \& Tung, 2005). Kemudian Myers (2012), menyatakan bahwa social loafing merupakan kecenderungan anggota kelompok untuk bersikap pasif atau memilih diam serta membiarkan orang lain untuk berusaha, mengerjakan, dan menyelesaikan tugas kelompok. Tidak terjalinnya kerjasama yang baik antar anggota kelompok tersebut menyebabkan terjadinya social loafing pada siswa. Hal ini dikarenakan dalam mengerjakan tugas secara berkelompok diperlukan kerjasama untuk mencapai suatu tujuan kelompok.

Munandar (2001), mengemukakan bahwa setiap kelompok kerja pasti memiliki sasaran yang harus dicapai. Sasaran kelompok belum tentu dapat diterima sepenuhnya oleh setiap anggota kelompok sehingga diperlukan kerja sama antar anggota kelompok. Tinggi-rendahnya kesepakatan anggota kelompok terhadap sasaran kelompok, serta dapat saling menerima anggota kelompok lainnya menunjukkan derajat kelekatan atau cohesiveness kelompok.

Kohesivitas merupakan suatu keadaan dimana para anggota kelompok saling tertarik satu sama lainnya dan termotivasi untuk tetap bertahan dalam kelompok (Robbins dan Judge, 2015). Forsyth (2010), menyatakan bahwa kohesi tidak hanya tentang kesatuan dalam kelompok atau friendliness tetapi kohesi merupakan berbagai proses yang berpengaruh terhadap proses interpersonal dan intragroup dalam kelompok tersebut. 
Penelitian Liden, dkk (2004), menunjukkan bahwa salah satu faktor yang mempengaruhi social loafing adalah kohesivitas. Hal ini disebabkan apabila anggota kelompok tidak saling menyukai atau tidak merasa dekat antar anggota kelompok lainnya maka akan menimbulkan kecenderungan social loafing. Sebaliknya, menurut Davis dan Greenless (Myers, 2012), apabila anggota kelompok saling bersahabat atau merasa mengenali atau memerlukan kelompok mereka maka kemalasan dalam kelompok tersebut akan berkurang.

\section{Metode}

\section{Populasi dan Sampel}

Populasi dalam penelitian ini adalah siswa di SMA Negeri 1 Indralaya yang berjumlah sebanyak 772 orang. Metode yang digunakan dalam menentukan sampel yaitu dengan teknik nonprobability sampling jenis purposive sampling. Pengambilan sampel menggunakan taraf kesalahan 5\% yang dikembangkan oleh Isaac dan Michael yaitu sebanyak 243 orang. Berdasarkan pertimbangan peneliti, maka jumlah sampel yang digunakan dalam penelitian ini yaitu sebanyak 250 orang. Kemudian jumlah sampel tryout yaitu berjumlah 100 orang.

\section{Pengumpulan Data}

Pengumpulan data menggunakan skala psikologis yaitu skala social loafing dan kohesivitas yang dibuat sendiri oleh peneliti. Instrumen skala psikologis yang digunakan tersebut berbentuk skala Likert. Skala social loafing mengacu pada teori yang dikemukakan oleh Chidambaram dan Tung (2005), yang menjelaskan bahwa dimensi dari social loafing adalah the dilution effect dan the immediacy gap. Sedangkan skala kohesivitas mengacu pada empat komponen kohesivitas yang diungkapkan oleh Forsyth (2010), yaitu social cohesion, task cohesion, perceived cohesion, dan emotional cohesion.

Validitas dalam penelitian ini dapat diketahui dengan cara mengkorelasikan aitem melalui bantuan SPSS versi 16.0 for windows. Sugiyono (2015), menyatakan bahwa korelasi aitem digunakan untuk mengkorelasikan jumlah skor faktor dengan skor total apabila korelasinya di atas $0,30(\geq 0,30)$ maka instrument tersebut merupakan konstruk yang kuat. Selanjutnya koefisien 
reliabilitas $\left(\mathrm{r}_{\mathrm{xx}}{ }^{\prime}\right)$ berada dalam rentang angka dari 0 sampai dengan 1,00. Bila koefisien reliabilitas semakin tinggi mendekati angka 1,00 maka pengukuran semakin reliabel (Azwar, 2016). Teknik yang digunakan untuk menghitung reliabilitas instrumen dalam penelitian ini menggunakan Alpha Cronbach dengan bantuan SPSS versi 16.0 for windows.

\section{Analisis Data}

Analisis data dalam penelitian ini terdiri dari uji asumsi dan uji hipotesis. Terdapat uji normalitas dan uji linieritas dalam uji asumsi. Metode yang digunakan untuk uji normalitas dalam penelitian ini adalah Kolmogorov-Smirnov dengan bantuan dari SPSS 16.0 for windows. Sebaran data dapat dikatakan normal jika nilai $\mathrm{p}>0,05$. Jika $\mathrm{p}<0,05$ maka sebaran data dinyatakan tidak normal (Hidayat, 2017). Selanjutnya uji linearitas terhadap kedua variabel dilakukan dengan Test for Linearity dengan bantuan dari SPSS 16.0 for windows. Berdasarkan pengujian linearitas, jika $\mathrm{p}<0,05$ maka hubungan antara variabel bebas dan variabel terikat dapat dinyatakan linear. Sebaliknya, jika p >0,05 maka hubungan antara variabel bebas dan variabel terikat dinyatakan tidak linear (Hidayat, 2017).

Kemudian teknik yang digunakan untuk menguji hipotesis dalam penelitian ini yaitu menggunakan teknik korelasi Pearson's Product Moment dengan bantuan dari SPSS 16.0 for windows. Sugiyono (2015), menyatakan bahwa teknik correlation product moment merupakan teknik yang tepat untuk digunakan pada data yang berbentuk interval atau rasio serta untuk mengetahui hubungan antara variabel bebas dan variabel terikat (Sugiyono, 2015).

\section{Hasil dan Pembahasan}

Subjek dalam penelitian ini berjumlah 250 orang yang berasal dari berbagai kelas di SMAN 1 Indralaya. Berdasarkan usia subjek terlihat bahwa sebanyak 138 orang $(55,2 \%)$ berusia 16 tahun, 73 orang $(29,2 \%)$ berusia 15 tahun, 34 orang $(13,6 \%)$ berusia 17 tahun dan sebanyak 5 orang (2\%) yang berusia 14 tahun. 
Selanjutnya berdasarkan jenis kelamin, diketahui sebanyak 178 orang (71,2 $\%)$ berjenis kelamin perempuan. Sedangkan orang yang berjenis kelamin laki-laki berjumlah sebanyak 72 orang $(28,8 \%)$. Kemudian deskripsi data penelitian dapat dilihat pada tabel 4.7 di bawah ini :

Tabel 1. Deskripsi Data Penelitian

\begin{tabular}{lcccccccc}
\hline \multirow{2}{*}{ Variabel } & \multicolumn{4}{c}{ Data Hipotetik } & \multicolumn{4}{c}{ Data Empiris } \\
\cline { 2 - 10 } & Max & Min & Mean & SD & Max & Min & Mean & SD \\
\hline Sosial Loafing & 68 & 17 & 42.5 & 8.5 & 50 & 18 & 30.86 & 5.352 \\
\hline Kohesivitas & 108 & 27 & 67.5 & 13.5 & 108 & 66 & 90.07 & 8.512 \\
\hline
\end{tabular}


Setelah melakukan analisis deskriptif, peneliti kemudian mengkategorisasikan subjek berdasarkan skor yang diperoleh yaitu menjadi tinggi, sedang, dan rendah. Berikut adalah formulasi pengkategorisasiannya:

Tabel 2. Kategorisasi Sosial Loafing Pada Subjek Penelitian

\begin{tabular}{cccc}
\hline Skor & Kategorisasi & Frekuensi & Persentase \\
\hline $\mathrm{X}<34$ & Rendah & 171 & $68.4 \%$ \\
\hline $34 \leq \mathrm{X}<51$ & Sedang & 79 & $31.6 \%$ \\
\hline $\mathrm{X} \geq 51$ & Tinggi & 0 & $0 \%$ \\
\hline Jumlah & & $\mathbf{2 5 0}$ & $\mathbf{1 0 0 \%}$ \\
\hline
\end{tabular}

Berdasarkan hasil kategori di atas, dapat diketahui bahwa social loafing pada subjek penelitian yang tergolong rendah sebanyak 171 orang $(68.4 \%)$, yang tergolong sedang sebanyak 79 orang (31.6\%), sedangkan yang tergolong tinggi yaitu $0 \%$.

Tabel 3. Kategorisasi Keohesivitas Pada Subjek Penelitian

\begin{tabular}{cccc}
\hline Skor & Kategorisasi & Frekuensi & Persentase \\
\hline $\mathrm{X}<54$ & Rendah & .0 & $.0 \%$ \\
\hline $54 \leq \mathrm{X}<81$ & Sedang & 32 & $12.8 \%$ \\
\hline $\mathrm{X} \geq 81$ & Tinggi & 218 & $87.2 \%$ \\
\hline Jumlah & & $\mathbf{2 5 0}$ & $\mathbf{1 0 0 \%}$ \\
\hline
\end{tabular}

Berdasarkan hasil kategorisasi di atas, dapat diketahui bahwa kohesivitas subjek penelitian yang tergolong tinggi yaitu sebanyak 218 orang (87.2\%), kemudian yang tergolong sedang yaitu sebanyak 32 orang $(12.8 \%)$, sedangkan yang tergolong rendah yaitu $0 \%$ ).

Uji hipotesis dilakukan dengan menggunakan formulasi korelasi pearson product moment yang dibantu oleh SPSS 16 for windows. Hasil uji hipotesis dapat dilihat dalam tabel 4.13 di bawah ini:

Tabel 4. Hasil Uji Hipotesis

\begin{tabular}{lccc}
\hline \multirow{2}{*}{ Variabel } & \multicolumn{2}{c}{ Korelasi } & \multirow{2}{*}{ Ket. } \\
\cline { 2 - 3 } & $\begin{array}{c}\text { Pearson } \\
\text { Correlation }\end{array}$ & Sig. & Hubungan Negatif \\
\hline Sosial Loafing- Kohesivitas & -0.745 & 0.000 & \\
\hline
\end{tabular}

Hasil uji hipotesis tersebut menunjukkan bahwa nilai korelasi antara social loafing dan kohesivitas yaitu $-0,745$ dengan signifikansi $0,000(\mathrm{p}<0,05)$. Nilai korelasi -0,745 menunjukkan bahwa ada korelasi negatif antara social loafing dan 
kohesivitas. Semakin semakin tinggi kohesivitas maka social loafing akan semakin rendah. Begitupun sebaliknya, menurunnya kohesivitas dapat meningkatkan social loafing. Dengan demikian, hipotesis penelitian ini diterima yaitu ada hubungan antara social loafing dan kohesivitas dalam pembelajaran kelompok pada siswa SMAN 1 Indralaya. Berdasarkan hasil analisis data yang diperoleh dari siswa SMAN 1 Indralaya dengan teknik korelasi pearson product moment menunjukkan bahwa ada hubungan antara kohesivitas dan social loafing dengan koefisien korelasi sebesar -0,745 dan signifikansi 0,000 ( $\mathrm{p}<0,05)$. Dengan demikian, hipotesis penelitian ini diterima. Nilai korelasi product moment -0,745 menunjukkan bahwa kohesivitas memiliki hubungan negatif dengan social loafing. Semakin tinggi kohesivitas maka social loafing semakin rendah. Sebaliknya, semakin rendah kohesivitas maka social loafing semakin meningkat. Hasil penelitian ini sesuai dengan pendapat Kunishima dan Welte (2004), yang menyatakan bahwa salah satu faktor yang dapat mengurangi social loafing adalah dengan tingginya tingkat kohesivitas sosial. Ketika tingkat kohesivitas sosial antar individu tinggi maka individu tidak terlibat dalam social loafing saat bekerja secara bersama-sama. Likert (Rakhmat, 2013), menyatakan bahwa kohesivitas kelompok berkaitan erat dengan produktivitas individu. Kemudian Liden, dkk (2004), menemukan bahwa social loafing dalam kelompok berhubungan dengan menurunnya kohesivitas.

Selanjutnya berdasarkan hasil analisis data yang dilakukan, diketahui bahwa sebanyak 171 siswa $(68.4 \%$ ) di SMAN 1 Indralaya memiliki social loafing yang rendah. Kemudian 79 siswa $(31.6 \%)$ tergolong sedang dan $0 \%$ yang tergolong tinggi. Rendahnya tingkat social loafing pada siswa di SMAN 1 Indralaya ini dapat disebabkan oleh berbagai faktor. Robbins dan Judge (2015), menyatakan bahwa terdapat hal yang dapat meminimalkan adanya social loafing yaitu meningkatnya kompetisi intragroup. Dapat diketahui bahwa SMAN I Indralaya merupakan salah satu sekolah unggulan di Indralaya. Hal ini dapat menunjukkan kompetisi siswa di sekolah tersebut meningkat.

Aronson, Wilson, dan Akert (2014), menyatakan bahwa social loafing merupakan kecenderungan bagi orang-orang untuk bersantai ketika adanya 
kehadiran orang lain dan kinerja individu lebih buruk saat mengerjakan tugas yang mudah dibandingkan pada saat mereka mengerjakan tugas yang sulit. Grace dan Shepperd (Baumeister \& Vohs, 2007), juga mengatakan bahwa social loafing dapat dipengaruhi oleh beberapa hal salah satunya yaitu saat tugas dipandang sebagai suatu hal yang mudah. Dapat diketahui bahwa SMAN 1 Indralaya saat ini telah mendekati ujian akhir semester sehingga banyak guru yang memberikan tugas akhir semester yang dianggap siswa cukup sulit dibandingkan tugas kelompok seperti hari biasanya. Berdasarkan teori-teori tersebut dapat disimpulkan bahwa saat individu mendapat tugas yang lebih sulit maka kecenderungan terjadinya social loafing semakin kecil dan kinerja individu menjadi lebih baik. Hal inilah yang mendukung rendahnya social loafing yang terjadi di SMAN 1 Indralaya.

Rendahnya social loafing pada siswa di SMAN 1 Indralaya juga disebabkan oleh meningkatnya kohesivitas antar siswa. Sesuai dengan hasil analisis data penelitian yang menunjukkan bahwa kohesivitas siswa di SMAN 1 Indralaya tergolong tinggi yaitu sebanyak 218 siswa (91,2 \%). Siswa yang memiliki kohesivitas yang tergolong sedang yaitu 32 siswa $(8,8 \%)$. Sedangkan 0 $\%$ siswa yang tergolong rendah kohesivitasnya. Tingginya kohesivitas pada pelajar di SMAN 1 Indralaya dikarenakan beberapa faktor. Salah satunya yaitu adanya interpersonal attraction atau ketertarikan antar individu yang satu dengan yang lainnya (Forsyth, 2010). Lott dan Lott (Forsyth, 2010), menyatakan bahwa terdapat beberapa faktor yang mempengaruhi interpersonal attraction, seperti kedekatan, frekuensi interaksi, kesamaan, saling melengkapi, adanya timbal balik, saling menghargai, dengan begitu mereka dapat mengubah kelompok yang belum sempurna menjadi kelompok yang kohesif.

Robbins dan Judge (2015) menyatakan bahwa cohesiveness merupakan suatu keadaan dimana para anggota kelompok saling tertarik satu sama lainnya dan termotivasi untuk tetap bertahan dalam kelompok tersebut. Kohesivitas dalam kelompok juga dipengaruhi oleh faktor anggota kelompok yang telah menghabiskan sebagian waktu mereka untuk bersama-sama. Diketahui siswa telah mengenal satu sama lainnya selama bertahun-tahun dan menghabiskan waktu 
bersama-sama di sekolah. Hal ini memungkinkan kohesivitas antar siswa di SMAN 1 Indralaya meningkat. Kohesivitas dalam kelompok dapat mempengaruhi produktivitas kelompok. Oleh karena itu, jika kohesivitas siswa meningkat maka social loafing siswa menurun.

\section{Kesimpulan dan Saran}

\section{Kesimpulan}

Berdasarkan hasil analisis terhadap data penelitian menunjukkan bahwa kohesivitas memiliki hubungan dengan social loafing.

Saran

1. Saran untuk Siswa SMAN 1 Indralaya

Siswa SMAN 1 Indralaya mampu mengatasi social loafing yang terjadi di kelompok. Siswa lebih meningkatkan kerja sama antar anggota kelompok untuk mencapai tujuan kelompok. Serta bertanggung jawab terhadap tugas kelompok yang diberikan oleh guru.

2. Saran untuk Tenaga Pendidik (Guru) SMAN 1 Indralaya

Guru harus memperhatikan dampak positif dan negatif dari setiap pembelajaran kelompok yang diberikan. Serta mampu menerapkan pembelajaran dan suasana kelas yang dapat meminimalkan terjadi social loafing yang terjadi dalam proses pembelajaran di kelas.

\section{Saran untuk Instansi (Sekolah) SMAN 1 Indralaya}

Instansi ikut memantau pembelajaran yang diberikan oleh guru kepada siswa untuk meningkatkan kualitas pembelajaran dan hasil belajar siswa. Serta proses belajar mengajar di kelas yang terjadi di kelas dapat berjalan secara efektif.

\section{Peneliti Selanjutnya}

Bagi peneliti selanjutnya, diharapkan dapat melibatkan faktor-faktor lainnya yang mungkin dapat mempengaruhi social loafing dan kohesivitas. Seperti halnya social loafing yang memungkinkan dapat dipengaruhi oleh work group size serta kohesivitas yang juga mungkin dapat dipengaruhi oleh interpersonal attraction dan commitment individu terhadap tugas. Selain itu, peneliti selanjutnya 
juga dapat meneliti mengenai dampak dari social loafing dan kohesivitas terhadap kinerja atau produktivitas kelompok.

\section{DAFTAR PUSTAKA}

Aronson, E.; Wilson, T.D.; Akert, R.M. (2014). Social Psychology: Pearson New International Edition (Ed.8). New York: Pearson Education, Inc.

Azwar, S. (2016). Metode Penelitian. Yogyakarta: Pustaka Pelajar.

Baumeister, R.F.; Vohs, K.D. (2007). Encyclopedia Of Social Psychology. United States Of America : Sage Publications, Inc.

Chidambaram, L., Tung, L.L. (2005). Is Out Of Sight, Out Of Mind? An Empirical Study Of Social Loafing In Technology-Supported Groups. Journal Information System Research, 16(2), 149-168. Doi: 10.1287/1050.0051.

Darmadi. (2017). Pengembangan Model Dan Metode Pembelajaran Dalam Dinamika Belajar Siswa. Yogyakarta: Deepublish Publisher.

Forsyth, R.D. (2010). Group Dynamics (Ed.5). Usa: Wadsworth, Cengage Learning.

Hidayat, A. (Februari, 2017). Tutorial Uji Normalitas Kolmogorov Smirnov Dengan Spss. Statistikian. Diunduh Dari Https://Www.Statistikian.Com/2012/09/Uji-Normalitas-DenganKolmogorov-Smirnov-Spss.Html/Amp 21 Agustus 2017

Hidayat, A. (Maret, 2017). Tutorial Regresi Dengan Spss. Statistikian. Diunduh Dari Https://Www.Statistikian.Com/2013/03/Linearitas-Regresi.Html/Amp 21 Agustus 2017

Hidayat, A. (September 2017). Penjelasan Tentang Uji Normalitas Dan Metode Perhitungan. Statistikian. Diunduh Dari Https://Www.Statistikian.Com/2013/01/Uji-Normalitas.Html 21 Agustus 2017

Kunishima. J., \& Welte, K. (2004, March). Effects Of Punishment Threats On Social Loafing. Journal of Young Investigators. 10(2).

Di unduh Dari

Http://Legacy.Jyi.Org/Volumes/Volume10/Issue3/Articles/Kunishima.Htm 120 Agustus 2017.

Liden, R.C, Dkk. (2004). Social Loafing: A Field Investigation. Journal of Management, 30(2), 285-304. Doi:10.1016/2003.02.002. 
Munandar, A.S. (2001). Psikologi Industry Dan Organisasi. Jakarta: Ui-Press

Myers, D.G. (2012). Psikologi Sosial (Ed.10). Jakarta: Salemba Humanika.

Myers, D.G., \& Jean, M.T. (2017). Social Psychology (Ed.12). Usa: Mcgraw-Hill.

Pangarso, A. (2016). Perilaku Organisasi (Ed.1). Yogyakarta: Deepublish.

Prastowo, A. (2015). Menyusun Rencana Pelaksaan Pembelajaran (Rpp) Tematik Terpadu Implementasi Kurikulum 2013 Untuk Sd/Mi. Jakarta: Kencana.

Rakhmat, J. (2013). Psikologi Komunikasi. Bandung: Pt Remaja Rosdakarya.

Robbins, S.P.; Judge, T.A. (2015). Perilaku Organisasi (Ed.16). Jakarta: Salemba Empat.

Sarinah; Mardalena. (2017). Pengantar Manajemen. Yogyakarta: Deepublish.

Sugiyono. (2015). Metode Penelitian Kuantitatif, Kualitatif, Dan $R \&$ D. Bandung: Alfabeta.

Sujarwo. (2010). Dinamika Pendidikan. Yogyakarta: Fip Universitas Negeri Yogyakarta.

Tyagi, P. (2015, January). Motivation And Inequities As Antecedents Of Social Loafing In Marketing Group Projects. Journal Of International \& Interdisciplinary Business Research, Vol.2. Diunduh Dari: Http://Scholars.Fhsu.Edu/Jiibr/Vol2/Iss1/9

Usman, B. (2002). Metodologi Pembelajaran Agama Islam. Jakarta: Ciputat Pers

Walgito, B. (2010). Psikologi Kelompok (Ed.3). Yogyakarta: C.V Andi Offset 